Nig. J. Biotech. Vol. 32 (2017) 20 - 27

ISSN: 01891731

Available online at

http://www.ajol.info/index.php/njb/index

and www.biotechsocietynigeria.org

DOI: http://dx.doi.org/10.4314/njb.v32i1.4

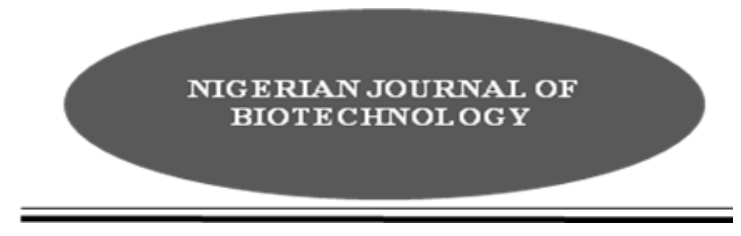

\title{
Effect of Bacteriocin-like Inhibitory Substances Produced by Vaginal Lactobacilli on Group B Streptococcus
}

\author{
Alajekwu, O. U. and Ike, A. C. \\ Department of Microbiology, University of Nigeria, Nsukka, Enugu State, Nigeria
}

\begin{abstract}
(Received: 22:12:2016; Accepted: 06:02:2017)
Abstract

Reduction of vaginal Lactobacillus population leads to overgrowth of opportunistic organisms such as Streptococcus agalactiae (Group B Streptococcus, GBS), which causes life threatening neonatal infections. The activities of bacteriocin-like inhibitory substances (BLIS) produced by Lactobacillus species isolated from the vagina of pregnant women were tested on GBS. Crude Bacteriocins were produced from seven Lactobacillus isolates using de Man Rogosa Sharpes media. Partial purification was done using ammonium sulphate saturation $(90 \%)$ and dialysis methods. The antibacterial effects of the crude and partially purified BLIS were carried out by disc Agar diffusion method. The BLIS from strains R5 and L2 gave the highest and lowest inhibition zone diameter (IZD) of $16.9 \mathrm{~mm}$ and $12.1 \mathrm{~mm}$, respectively, for the crude extracts and $18.5 \mathrm{~mm}$ and $14.2 \mathrm{~mm}$, respectively, for the partially purified extracts. All the BLIS had their strongest activity at $30^{\circ} \mathrm{C}$ and decreased with increase in temperature. BLIS from strains L3 and L4 lost their activities at $100^{\circ} \mathrm{C}$. The activities of all the BLIS were higher at acidic pH. The IZD of the combined crude extract was $19.06 \mathrm{~mm}$, while that of the combined partially purified extracts was $21.07 \mathrm{~mm}$. The combined BLIS had higher activity than each of the single compound. There were no statistical difference between the sensitivities of the partially purified BLIS and the crude BLIS ( $P$ > 0.05). The findings of this study show that BLIS produced by vaginal Lactobacilli spp. can be used as probiotics for the control of GBS and that combining the BLIS may be more effective.
\end{abstract}

Keywords: Antibacterial, Group B Streptococci, Vaginal Lactobacillus

Correspondence: anthonyc.ike@unn.edu.ng

\section{Introduction}

Lactobacillus species are nonpathogenic Gram-positive rods that are predominantly isolated from the vagina of healthy premenopausal women (Reid and Burton, 2002). The vaginal flora in healthy premenopausal women contains Lactobacillus spp, which occur in the range of $10^{7}-10^{8} \mathrm{cfu} / \mathrm{g}$ fluid (Pascual et. al., 2008b). Some Lactobacilli produce bacteriocins and other compounds like hydrogen peroxide and lactic acid as a means of protecting the vagina against pathogenic/opportunistic microorganisms (Ocana et. al., 1999). Some strains such as L. gasseri
EV1461 have been shown to specifically inhibit the growth of pathogens associated with bacteria vaginosis (Maldonnado-Barragán et. al., 2016). The protective role of Lactobacilli in the vagina becomes evident when their concentrations drop as a result of the use of antibiotics or in an immune-compromised host. This drop in concentration favors colonization by intestinal bacteria and the overgrowth of opportunistic organisms (Reid and Burton, 2002; Martin et al., 2008).

Bacteriocin-like substances (BLIS) are ribosomally-synthesized antimicrobial peptides that are not completely defined and do not fit 
the typical criteria of bacteriocins. Unlike bacteriocins with activities only on species closely related to the producing organism, BLIS have been shown to have broader activities and are reported to inhibit a wide range of both Gram-positive and Gram-negative bacteria as well as fungi (McGoarty, 1993). Most bacteriocins from lactic acid bacteria have been isolated from species of the genus Lactobacillus, because of the diversity of its species and habitats.

Group B Streptococci (GBS) are among the opportunistic organisms that colonize the lower gastrointestinal and genitourinary tracts of 30 to $50 \%$ of healthy adults. An estimated 10 to $30 \%$ of all pregnant women are carriers of GBS (CDC, 1996). Streptococcus agalactiae (GBS) is a significant cause of perinatal and neonatal infections worldwide and is responsible for 1.8 neonatal infections per 1000 live birth per year (CDC, 1996). The organism can be acquired during delivery or in utero by transmission from maternal vaginal or anorectal-colonized mucosa (Edward et. al., 2005). Colonization in late pregnancy can result in poor pregnancy outcome because GBS has the ability to penetrate intact amniotic membrane causing amnionitis which could lead to miscarriage (Hansen et al., 2004).

Few studies have been done on the effect of bacteriocin on GBS; this study is therefore aimed at determining the effect of BLIS produced by Lactobacillus on GBS.

\section{Materials and methods}

Specimen collection and isolation of Lactobacillus

A total of eighty-seven (87) samples were collected from pregnant women at the University of Nigeria Medical Centre and Bishop Shanahan hospital both in Nsukka, Nigeria. Vaginal fluids were taken from the lateral wall of the vagina using a sterile cotton swab and were transported immediately to the Microbiology laboratory, University of Nigeria, Nsukka. Vaginal swabs were inoculated on Man Rogosa Sharpes (MRS) agar plates by streaking method. They were incubated at $37^{\circ} \mathrm{C}$ for $48 \mathrm{~h}$ and suspected colonies were subcultured to obtain pure culture.

\author{
Isolation and identification of Group $B$ \\ Streptococcus \\ Vaginal swabs for Group B Streptococcus \\ isolation were immersed in Todd-Hewitt broth \\ (CMO 189 Oxoid, England) for 1 minute and
}

then pressed lightly against the side of the tube. The tube was incubated at $37^{\circ} \mathrm{C}$ for $24 \mathrm{~h}$ under anaerobic condition. Growth in the culture broth was streaked on $5 \%$ sheep blood agar plates and the plates incubated for $24 \mathrm{~h}$ at $37^{\circ} \mathrm{C}$. Colonies showing clear zones around the colonies were picked and subcultured. Gram staining was carried out with a freshly prepared culture and catalase test was performed.

\section{Bacterial identification}

The isolates were identified according to their morphological, cultural and biochemical characteristics. Identification of Lactobacillus spp was based on comparison of observed characteristics of isolates with those of lactic acid bacteria described in the Bergey's Manual of Determinative Bacteriology (Holt et al., 1994). Group B Streptococcus was identified using Gram staining, catalase test and Christie, Atkins, and Munch-Peterson (CAMP) test.

\section{Production of Crude Bacteriocin-like inhibitory substance (BLIS)}

Bacteriocin-like inhibitory substances are proteins produced extracellularly into the culture broth. Three hundred (300) $\mathrm{ml}$ of MRS broth were inoculated with $1 \% \mathrm{v} / \mathrm{v}$ of the overnight cultures of the identified Lactobacillus isolates and incubated at $37^{\circ} \mathrm{C}$ for $48 \mathrm{~h}$ anaerobically in triplicates. After incubation, cells were separated by centrifugation at $5000 \mathrm{~g}$ for $30 \mathrm{~min}$ in a table centrifuge (Galenkamp, England). The supernatants were adjusted to $\mathrm{pH} 6.5$ using $1 \mathrm{~N}$ sodium hydroxide $(\mathrm{NaOH})$ to remove the effect of organic acid and $5 \mathrm{mg} / \mathrm{ml}$ catalase (Sigma, England) was also added to remove the inhibitory effect of hydrogen peroxide. The supernatants were filtered using $0.45 \mu \mathrm{m}$ pore size membrane filter to obtain crude BLIS present in the cell-free supernatant (Aslim and Kilic, 2006).

\footnotetext{
Production of partially purified BLIS ammonium sulphate precipitation of bacteriocin

Ammonium sulphate precipitation ( $90 \%$ saturation) was carried out by gently dissolving $90.45 \mathrm{~g}$ of the salt in the cell-free supernatant and stirring gently till the salt was completely dissolved. The precipitate were redissolved in 6 $\mathrm{ml}$ of $0.05 \mathrm{M}$ sodium phosphate buffer ( $\mathrm{pH} 7.0$ ) after centrifugation and then kept under cold condition for further use.
} 


\section{Dialysis}

The precipitated BLIS solution was carefully poured into dialysis bags and tightly tied with thread. Sodium phosphate $(0.05 \mathrm{M})$ buffer $(\mathrm{pH}$ 7.0) was used for protein dialysis. Dialysis was carried out for $18 \mathrm{~h}$ with continuous stirring using magnetic stirrer at $4^{\circ} \mathrm{C}$ and buffer changed every $6 \mathrm{~h}$ with a view to removing low molecular weight substances and other ions that may interfere with protein activity. After dialysis was completed, the partially purified bacteriocin was adjusted to $\mathrm{pH} 6.5$ using $\mathrm{NaOH}$ and sterilized by passing through a $0.45 \mu \mathrm{m}$ membrane filters.

\section{Preparation of the Test Organism and Determination of inhibitory spectrum of bacteriocin}

Overnight culture of GBS was inoculated in broth and after incubation at $37^{\circ} \mathrm{C}$ for $24 \mathrm{~h}$ was diluted and matched with Mc Farland No. 0.5 standard. The number of organisms present in the culture was estimated using standard plate count. Culture tube containing about $5 \mathrm{x}$ $10^{8}$ cells $/ \mathrm{ml}$ was used for the sensitivity test. Bacteriocin assay was carried out by disk diffusion method.

\section{Effect of hydrogen ion concentration $(\mathrm{pH})$ on BLIS}

The effects of the crude and purified extracts on the target organism were examined at $\mathrm{pH} 5.5,6.0,7.5,8.0$. The samples were adjusted to different $\mathrm{pH}$ using $1 \mathrm{~N} \mathrm{NaOH}$ and $1 \mathrm{~N}$ Hydrochloric acid $(\mathrm{HCl})$ using Hanna $\mathrm{pH}$ meter (Hanna Instruments, USA). The samples were filtered with $0.45 \mu \mathrm{m}$ membrane filters after the adjustment, and then used for antibacterial sensitivity testing.

\section{Effect of Temperature on BLIS}

Equal volumes of extracts were heated at $30^{\circ} \mathrm{C}, 40^{\circ} \mathrm{C}, 50^{\circ} \mathrm{C} ; 60^{\circ} \mathrm{C}, 70^{\circ} \mathrm{C}, 80^{\circ} \mathrm{C}, 90^{\circ} \mathrm{C}$ and $100^{\circ} \mathrm{C}$ for $10 \mathrm{~min}$ using water bath. The samples were cooled immediately in the fridge before testing against the target organism.

\section{Combined effect of two BLIS}

Two extracts with the highest activity were mixed together at equal concentration. Their effects were tested on test organism. The effects of $\mathrm{pH}$ and temperature on combined BLIS were also examined.

\section{Results}

\section{Identification of isolates}

Among the 87 samples collected from the vaginas of pregnant women, Lactobacillus spp. was recovered from $7(8.1 \%)$. The test organism (GBS), which had a wide clear zone on blood agar, was identified using cultural and biochemical characteristics. The cultural and biochemical characteristics of the Lactobacillus isolates are shown in Table 1 . Only isolate L6 was able to grow at $15^{\circ} \mathrm{C}$, while isolates $\mathrm{R} 6$ and L3 were able to grow at $45^{\circ} \mathrm{C}$. All the strains were capable of fermenting glucose, lactose and maltose, except isolate R1, which gave weak reaction for maltose, while only isolate L2 produced gas from glucose. All the isolates fermented sucrose except isolates L3 and L4. L6 fermented all the sugars except xylose. Based on the reactions, the probable organisms were identified as shown in Table 1.

The Inhibitory activities produced by each Bacteriocin-like inhibitory substance (BLIS) of Lactobacillus species on GBS.

All the crude and partially purified extract of Lactobacillus spp. strain showed some inhibitory activity against the test organism (Figure 1). The test organism was more sensitive to the partially purified extracts than the crude extracts but the differences were not statistically different $(p>0.05)$. Strain R5 had the highest inhibitory spectrum of the crude extract at 16.9 $\mathrm{mm}$ followed by R6 at $16.1 \mathrm{~mm}$, while strain L2 had the lowest activity at $12.1 \mathrm{~mm}$. The partially purified extracts followed the same pattern, with strains R5 and L2 having the highest and lowest inhibitory spectrum respectively (Figure 1 ).

The BLIS from almost all the isolates maintained activity at the tested temperature range $\left(30-100^{\circ} \mathrm{C}\right)$ for 10 min except for $L 3$ and L4 that lost their activities at $100^{\circ} \mathrm{C}$. The BLIS from all the isolates had their strongest activities at $30^{\circ} \mathrm{C}$. The zones of inhibition decreased as the temperature was increased (Table 2). The BLIS compounds were active at a wide range of $\mathrm{pH}$ but were generally more active at acidic $\mathrm{pH}$ than at alkaline $\mathrm{pH}$ (Figures 2 and 3).

The combined effect of two BLIS with highest activity on Group B Streptococci (GBS)

The result of the individual inhibitory capacity showed that R6 and R5 had the highest 
activities against the target organism (Table 1). The combination of BLIS from these two isolates is shown in Table 3. The zone of inhibition of the combined crude BLIS was $19.06 \mathrm{~mm}$, while that of the partially purified extracts was $21.07 \mathrm{~mm}$. The combined inhibitory compound was active at a wide range of $\mathrm{pH}(\mathrm{pH} 5.5-8.0)$ and temperatures. They were stable between temperatures $30^{\circ} \mathrm{C}$ to $60^{\circ} \mathrm{C}$ (Table 4).

\section{Discussion}

Vaginal Lactobacilli designated as L6, $\mathrm{R} 6, \mathrm{R} 5, \mathrm{~L} 2, \mathrm{RI}, \mathrm{L} 3$ and L4 were isolated from pregnant women and identified based on cultural and biochemical characteristics. The biochemical characteristics of our isolates are comparable with vaginal Lactobacillus isolated from other studies (Alpay et al., 2002; Aslim and Kilic, 2006; Anukam and Reid, 2007; Martin et al., 2008; Pascual et al., 2008a; Gordana et al., 2011).

Aslim and Kilic (2006) found $16 \%$ L. acidophilus in healthy women, while Li et al. (2011) reported high rate $(76.9 \%)$ of vaginal $L$. acidophilus in pregnant women. Lactobacillus species are generally isolated from the vaginas of healthy women were they provide protection against opportunistic pathogens. However the low prevalence of Lactobacilli reported in this study suggests that absence of Lactobacilli does not indicate the presence of an infection. A study carried out by Patras et al. (2015), showed that Streptococcus salivarius, which is predominantly an oral bacterium not only demonstrated a good interaction with human vaginal epithelial cells but was able to reduce the GBS load in the vaginal tract of model animals. Although the study did not attempt isolating pathogenic bacteria, none of the patients reported symptoms of vaginitis.

The antimicrobial activity produced by our isolates were as a result of bacteriocin/bacteriocin-like inhibitory substances, as their inhibitory activities were not lost after treatment with catalase or adjustment of $\mathrm{pH}$. It has been shown that bacteriocin/BLIS produced by vaginal Lactobacillus have antimicrobial activity on Gram positive and closely related organisms (Pascual et al., 2008a; Tahara and Kanatani, 1997; Bogovic-Matijasic et al., 1998; Alpay et al., 2002; Razak et al., 2011). Similarly, BLIS produced by our isolates were able to inhibit the test organism (GBS). Our finding is in agreement with the study of Strus et al. (2002), who reported the inhibition of GBS by species of Lactobacillus. Our findings are also consistent with the findings of Ruiz et al. (2012) where BLIS produced by $L$. fermentum and $L$. rhamnosus were found to inhibit the growth of GBS.

The combination of the BLIS from the two most active Lactobacillus species showed higher inhibitory activity than the individual BLIS. This is in agreement with the findings of Ruiz et al. (2012), who reported better performance of combined BLIS from $L$. rhamnosus $L 60$ and $L$. fermentum L23 on GBS. However, while their combination resulted in a significant increase in activity, there was no significant difference in the activity of the combined BLIS in this study.

Activities of BLIS from the isolates were moderately heat stable as the effect of temperature was tested for only $10 \mathrm{~min}$. Isolate L3 lost its activity at $100^{\circ} \mathrm{C}$ in $10 \mathrm{~min}$ and therefore may be heat-labile. Many of the bacteriocins/BLIS produced by lactic acid bacteria are only stable at acidic and neutral $\mathrm{pH}$ and are inactivated at a pH above 8.0 (De Vuyst and Vandamme, 1994). These findings are consistent with our results; BLIS from our isolates were active over a wide $\mathrm{pH}$ range $(\mathrm{pH}$ 5.5-8.0) with highest activities at the acidic $\mathrm{pH}$. BLIS from isolates $L 6, R 6, L 2, L 3$, and-L4 had highest activity at $\mathrm{pH}$ 5.5. The combined BLIS in this study showed more stability against variations in both temperature and $\mathrm{pH}$ when compared with the BLIS of the individual isolates.

There was consistent improvement in activities of all the partially purified BLIS when compared with those of the crude BLISes, reflecting the success of the purification method used. However, there was no statistical difference between the degrees of sensitivity of partially purified BLIS and the crude BLIS $(p<0.05)$. This could be attributed to purification process used. Different purification methods have been reported to result in different levels of purification and yields, with no particular method being recommended due to the heterogeneous nature of bacteriocins (Pingitore et al., 2007). Song et al. (2014) reported that in the purification of plantaricin ZJ5, whereas ammonium sulphate precipitation gave a purification fold of 4.2 and specific activity of 317.14 AU/mg, C18 reverse-phase HPLC resulted in 139.5 purification fold and $10,576.92 \mathrm{AU} / \mathrm{mg}$ 
specific activity. In preparation of the partially purified BLIS, samples were dialyzed against buffer in dialysis tubing with a molecular weight cutoff of $10,000-12,000$. This suggests that the BLIS may be low molecular weight molecules.

In conclusion, the BLIS produced by Lactobacilli spp isolated from vagina of pregnant women in this study inhibited the growth of GBS at different $\mathrm{pH}$ and temperature ranges, which suggests its usefulness as a probiotics and an alternative to antibiotics. The effect of the combined BLIS was stronger with higher heat stability than individual BLIS suggesting that combination of bacteriocins may be more effective.

Table 1. Cultural and biochemical characteristics of isolates

\begin{tabular}{|c|c|c|c|c|c|c|c|c|c|c|c|c|c|c|c|c|c|}
\hline 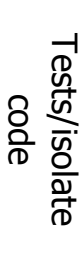 & 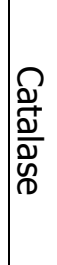 & 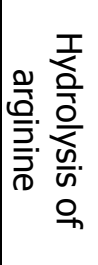 & 胫高 & 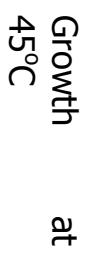 & 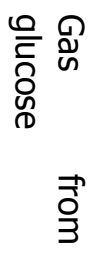 & 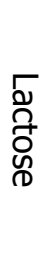 & 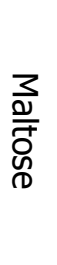 & 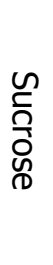 & 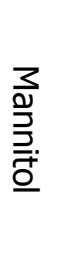 &  & 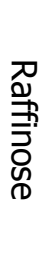 & 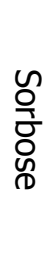 & 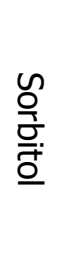 & 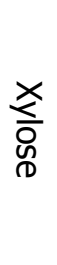 & 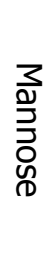 & 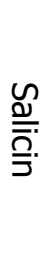 & 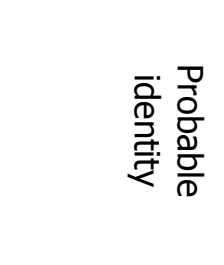 \\
\hline L6 & - & - & + & - & - & + & + & + & + & $\mathrm{w}$ & + & + & + & - & + & + & L. plantarum \\
\hline R6 & - & - & - & + & - & + & + & + & - & - & - & - & - & - & + & + & L. acidophilus \\
\hline R5 & - & - & - & - & - & + & + & + & - & - & - & w & - & - & + & - & L. $s p$ \\
\hline L2 & - & + & - & - & + & + & + & + & w & + & + & - & - & w & - & - & L. fermentum \\
\hline R1 & - & - & - & - & - & - & w & + & + & - & + & - & + & w & - & + & L. rhamnosus \\
\hline L3 & - & - & - & + & - & + & + & - & - & - & - & w & - & - & + & + & L. acidophilus \\
\hline L4 & - & - & - & - & - & + & + & - & w & w & - & w & - & + & w & + & L. $s p$ \\
\hline
\end{tabular}

Table 2. Effect of temperature on the inhibitory activity of crude and partially purified BLIS

\begin{tabular}{llllllll}
\hline TEMPERATURE & \multicolumn{7}{l}{ INHIBITION ZONE DIAMETER (MM) FOR CRUDE/PURIFIED EXTRACTS } \\
\cline { 2 - 8 } & L6 & R6 & R5 & L2 & R1 & L3 & L4 \\
$30^{\circ} \mathrm{C}$ & $13.4 / 15.0$ & $16.7 / 17.4$ & $15.3 / 17.4$ & $12.8 / 14.0$ & $12 / 14.3$ & $14.8 / 16.0$ & $15.3 / 16.1$ \\
$40^{\circ} \mathrm{C}$ & $13.2 / 14.1$ & $15.2 / 16.4$ & $15.1 / 17.2$ & $12.8 / 13.8$ & $12 / 14.0$ & $13.9 / 15.0$ & $14.8 / 15.8$ \\
$50^{\circ} \mathrm{C}$ & $11.5 / 13.2$ & $15.0 / 16.1$ & $15.3 / 16.6$ & $12.6 / 13.8$ & $11.8 / 14.0$ & $13.3 / 15.2$ & $14.1 / 15.2$ \\
$60^{\circ} \mathrm{C}$ & $11.3 / 12.5$ & $15.0 / 15.6$ & $14.1 / 15.4$ & $11.3 / 12.6$ & $11.9 / 14.1$ & $13.1 / 14.1$ & $12.5 / 14.3$ \\
$70^{\circ} \mathrm{C}$ & $11.3 / 11.7$ & $12.9 / 13.4$ & $12.3 / 14.1$ & $10.5 / 11.7$ & $11.8 / 13.8$ & $11.9 / 13.6$ & $12.1 / 14.4$ \\
$80^{\circ} \mathrm{C}$ & $10.3 / 11.0$ & $9.4 / 13.0$ & $11.2 / 13.8$ & $10.6 / 11.0$ & $11.4 / 12.8$ & $11.1 / 13.4$ & $10.9 / 13.4$ \\
$90^{\circ} \mathrm{C}$ & $10.0 / 11.1$ & $9.0 / 11.3$ & $11.1 / 12.3$ & $10.0 / 10.8$ & $11.2 / 12.4$ & $10.2 / 12.4$ & $9.2 / 10.2$ \\
$100^{\circ} \mathrm{C}$ & $9.4 / 10.0$ & $8.9 / 9.6$ & $9.2 / 11.4$ & $9.6 / 10.3$ & $11.0 / 12.8$ & $0.0 / 9.2$ & $0.0 / 0.00$ \\
\hline
\end{tabular}


Table 3. Effect of pH on the inhibitory activity of the combined BLIS of strains R5 and R6

\begin{tabular}{|c|c|}
\hline Parameters & Zones of inhibition (mm) \\
\hline Crude extract (6.5) & $19.06 \pm 0.06$ \\
\hline Partially purified extract (Ppe) (6.5) & $21.07 \pm 0.06$ \\
\hline Ppe at pH 5.5 & $20.10 \pm 0.10$ \\
\hline pH 6.0 & $21.20 \pm 0.17$ \\
\hline pH 7.0 (control) & $20.03 \pm 0.21$ \\
\hline pH 7.5 & $20.00 \pm 0.10$ \\
\hline $\mathrm{pH} 8.0$ & $18.00 \pm 0.10$ \\
\hline
\end{tabular}

Values are the means \pm standard deviations of triplicate measurements

Table 4. Inhibitory activity of the combined BLIS of strains R5 and $R 6$ at different temperatures.

\begin{tabular}{cl}
\hline Temperature & Zones of inhibition (mm) \\
\hline $30^{\circ} \mathrm{C}$ & $21.00 \pm 0.17$ \\
$40^{\circ} \mathrm{C}$ & $21.03 \pm 0.15$ \\
$50^{\circ} \mathrm{C}$ & $21.07 \pm 0.12$ \\
$60^{\circ} \mathrm{C}$ & $21.07 \pm 0.15$ \\
$70^{\circ} \mathrm{C}$ & $20.03 \pm 0.25$ \\
$80^{\circ} \mathrm{C}$ & $21.07 \pm 0.12$ \\
$90^{\circ} \mathrm{C}$ & $19.80 \pm 0.10$ \\
$100^{\circ} \mathrm{C}$ & $20.07 \pm 0.25$ \\
\hline
\end{tabular}

Values are the means \pm standard deviations of triplicate measurements

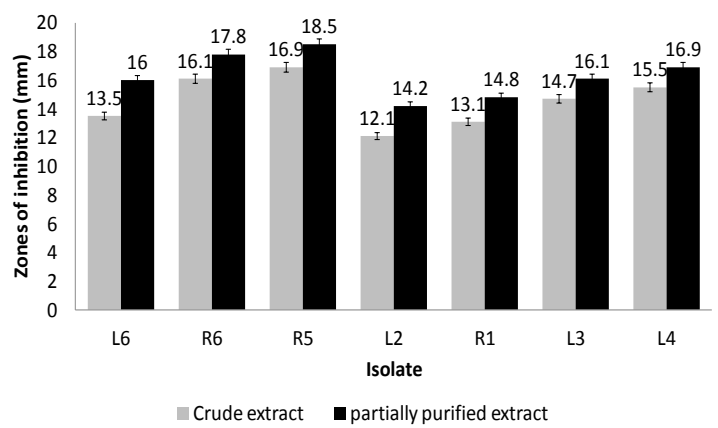

Figure 1: Inhibitory spectrum of crude and partially purified extract of Lactobacillus spp against test organism

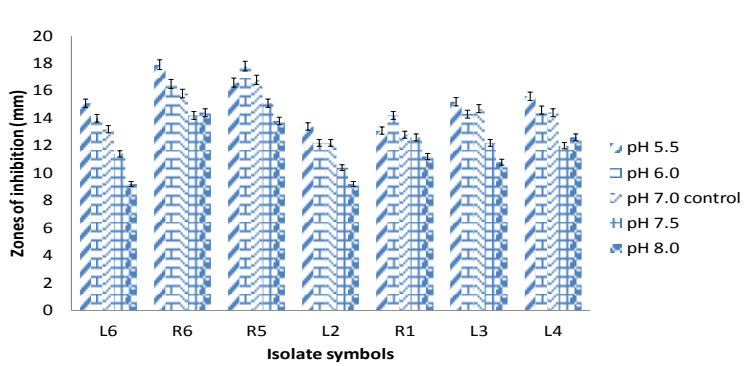

Figure 2: Effect of $\mathrm{pH}$ on the inhibitory activity of crude extracts of BLIS 


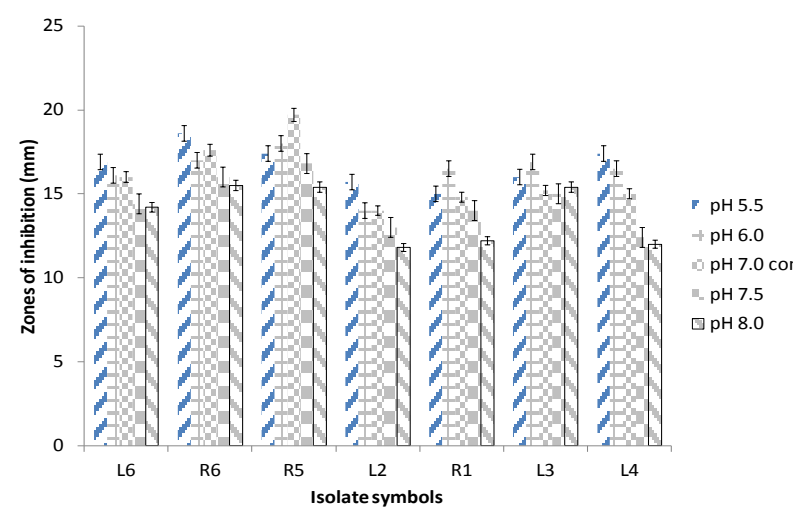

Figure 3: Effect of pH on the inhibitory activity of partially purified extracts of BLIS

\section{References}

Alpay K. S., Aydin, F., Kilc, S. S. and Kilic, A. O. (2003). Antimicrobial activity and characteristics of bacteriocins produced by vaginal Lactobacilli. Turk J. Med Sci. 33:7-13.

Anukam, K. S. and Reid, G. (2007). Lactobacillus plantarum and Lactobacillus fermentum with probiotic potentials isolated from the vagina of healthy Nigerian women. Res. J. Microbiol. 2:8187.

Aslim, B. and Kilic, E. (2006). Some probiotic properties of vagina Lactobacilli isolated from healthy women. Jpn J. Infect Dis. 59:249-253.

Bogovic-Matijasic, B., Rogelj, I., Nes, I. F. and Holo, H. (1998). Isolation and Characterization of two Bacteriocins of Lactobacillus acidophilus LF 22 1. Appl. Microbiol. Biotechnol. 49:606-612.

Centers for Disease Control and Prevention (1996). Prevention of perinatal group B streptococcal disease: a public health perspective. Morbid. Mortal. Weekly Rep. 45:124.

De Vuyst, L. and Vandamme, E. J. (1994). Bacteriocins of lactic acid bacteria: Microbiology, Genetics and Applications. London: Blackie Academic and Professional. ISBN 0-75140172-9.

Edward, M. S., Rench, M. A., Hafer, A. A. M., Murphy, M. A., Desmond, M. M. and Baker, C. J. (2005). Long term sequele of group $B$
Streptococcal meningitis. Inf. J. Paediatric. 106:717-722.

Gordana, Z., Zeljika, R., Valentina, V., Jelena, B., Topisirovic, L. and Ivana, S. (2011). Charaterization and antimicrobial activity of vaginal Lactobacillus isolate. Arch. Biol. Sci. Belgrade 63(1):29-35.

Hansen, S. M., Uldbjerg, N., Kilian, M. and Sørensen, U. B. (2004). Dynamics of Streptococcus agalactiae colonization in women during and after pregnancy and in their infants. J. Clin. Microbiol. 42:83-89.

Holt, J. G., Kreig, N. R., Sneath, P. H. A., Stanley, J. T. and Williams, S. T. (1994). Bergey's Manual of Determinative Bacteriology. Williams and Wilkins Baltimore, M. D.

Li, L., Hain-mg, Y. and Jianng, S. (2011). Vaginal Lactobaccilus distributions and functions in pregnant women. Afr. J. Microbiol. Res. 5(10):1224-1230.

Maldonado-Barragán, A., Caballero-Guerrero, B., Martín, V., Ruiz-Barba, J. L. and Rodríguiz, J. M. (2016). Purification and genetic characterization of gassericin $\mathrm{E}$, a novel co-culture inducible bacteriocin from Lactobacillus gasseri EV1461 isolated from the vagina of a healthy woman. BMC Microbiol. 16:37.

Martin. R., Soberon, N., Vaneechoulle, M., Florez, A. B., Vazquez, F. and Suarez J. E. 
(2008). Characterization of indigenous vaginal Lactobacilli from healthy women as probiotic candidates. Inter. Microbiol. 11:261-266.

McGoarty, J. (1993). Probiotic use of lactobacilli in the human female urogenital tract. FEMS Immunol. Med. Microbiol. 6:251-264.

Ocana, V. S., Aida, A, P. and Maria, E. N. (1999). Characterization of a bacteriocin-like substance produced by a vaginal Lactobacillus salivarius strain. Appl. Environ. Microbiol. 65(12):56315635.

Pascual, L. M., Daniele, M. B., Giordano, W., Pajaro, M. C. and Barberis, I. L. (2008a). Purification and partial characterization of Novel Bacteriocin L23 produced by Lactobacillus fermentum L23. Curr. Microbiol. 56:397-402.

Pascual, L. M., Daniele, M. B., Ruiz. F., Giordano, W., Pajaro, C. and Barberis, L. C. (2008b). Lactobacillus rhamnosus -60 , a potential probiotic isolated from the human vagina. J. Gen. Appl. Microbiol. 54:141-148.

Patras, K. A., Wescombe, P. A., Rösler, B., Hale, J. D., Tagg, J. R. and Doran, K. S. (2015). Streptococcus salivarius K12 limits Group B streptococcus vaginal colonization. Infect Immun. 83(9):3438-3444.

Pingitore, E. V., Salvucci. E., Sesma, F. and Nader-Macias, M. E. (2007). Different strategies for purification of antimicrobial peptides from Lactic Acid Bacteria (LAB). In: Communication Current Research and Educational Topics and Trends in Applied Microbiology. Méndez-Vilas, A. (Ed.) Formatex. Pp 557-568.
Razzak, M. S. A., Al-Charrakh, A. H. and AlGreitty, B. H. (2011). Relationship between Lactobacilli and opportunistic bacterial pathogens associated with vaginitis. North Am. J. Med. Sci. 3(4):185-192.

Reid, G. and Burton, J. (2002). Use of Lactobacillus to prevent infection by pathogenic bacteria. Microbes Infect. 4:319-324.

Ronnqvist, D. (2007). Urogenital probiotics: potential role of Lactobacillus in the prevention of urogenital infections in women. 1128 ISSN 0346-6612.

Ruiz, F. O., Gerbaldo, G., Garcia, M. J., Giordano, W., Pascula, L. and Barberis, I. L. (2012). Synergistic effect between two bacteriocin-like inhibitory substances produced by Lactobacilli strains with inhibitory activity for Streptococcus agalactiae. Curr. Microbiol. 64(4):349-356.

Song, D-F., Zhu, M-Y. and Gu, Q. (2014). Purification and characterization of Plantaricin ZJ5, a new bateriocin produced by Lactobacillus plantarum ZJ5. PLos One 9(8): e105549.

Strus, M., Malinowska, M. and Heczko, P. B. (2002). In vitro antagonistic effect of Lactobacillus on organisms associated with bacterial vaginosis. J. Reprod. Med. 47:41-46.

Tahara, T. and Kanatani, K. (1997). Isolation and partial characterization of Crispacia A, a cellassociated bacteriocin produced by Lactobacillus crispatus JCM 2009 FEMS Microbial Lett 147:287-290. 